\title{
Budaya Peningkatan Keselamatan Pasien di Puskesmas
}

\section{Aruni Muharani}

\author{
arunikisaran@gmail.com
}

Latar Belakang: Keselamatan pasien merupakan salah satu indikator kualitas pelayanan kesehatan. Meskipun data insiden keselamatan pasien di fasilitas pelayanan kesehatan tingkat pertama belum akurat di Indonesia, namun keselamatan pasien menjadi isu penting dalam peningkatan kualitas pelayanan. Puskesmas adalah salah satu fasilitas pelayanan kesehatan yang menerapkan upaya keselamatan pasien sebagai salah satu bentuk upaya peningkatan mutu pelayanan kesehatan sebagaimana dimaksud dalam Undang-Undang Republik Indonesia Nomor 36 Tahun 2009.

Puskesmas merupakan salah satu fasilitas pelayanan kesehatan yang bertanggung jawab menyelenggarakan upaya kesehatan, baik promotif, preventif, kuratif, maupun rehabilitatif di suatu wilayah kerja. Puskesmas sebagai penyelenggara pembangunan kesehatan merupakan bagian integral dari pembangunan nasional. Tujuan diselenggarakannya pembangunan kesehatan adalah meningkatkan kesadaran, kemauan dan kemampuan hidup sehat bagi setiap orang agar terwujud derajat kesehatan masyarakat yang optimal, baik secara sosial maupun ekonomi nya.

Berdasarkan Permenkes No. 46 Tahun 2015 tentang Akreditasi Puskesmas, Klinik Pratama, Tempat Praktik Mandiri Dokter, dan Tempat Praktik Mandiri Dokter Gigi pada bagian lampiran I Standar Akreditasi Puskesmas menyebutkan bahwa agar Puskesmas dapat menjalankan fungsinya secara optimal dan oerlu dikelola dengan baik mulai dari sumber daya yang digunakan, proses pelayanan hingga kinerja pelayanaan sebab masyarakat menuruti bahwa pelayanan kesehatan yang aman dan bermutu, serta merta mereka mendapatkan kebutuhan mereka. Oleh karena itu upaya peningkatan mutu, manajemen risiko dan keselamatan pasien sangatlah perlu diterapkan dalam pengelolaan Puskesmas dalam memberikan pelayanan kesehatan yang komprehensif kepada masyarakat melalui upaya pemberdayaan masyarakat dan swasta, sehingga dapat di terima oleh masyarakat.

Seluruh tindakan dalam pelayanan kesehatan dilaksanakan sesuai dengan standar pelayanan minimal dan kode etik profesi tenaga kesehatan. Tingginya angka insiden keselamatan pasien menjadi dasar sangat pentingnya upaya keselamatan pasien di fasilitas pelayanan kesehatan. Banyak faktor yang dapat menyebabkan melonjaknya angka Insiden Keselamatan Pasien (IKP) di fasilitas pelayanan kesehatan. Selain faktor penyebab tersebut, dampak yang dapat ditimbulkan dari Insiden Keselamatan Pasien juga sangat beragam, salah satunya yaitu berkurang nya angka kepuasan pasien sehingga dapat memberi pengaruh besar terhadap mutu dari pelayanan kesehatan tersebut. Pelayanan yang aman dapat meningkatkan angka kepuasan pasien sehingga dapat memberikan pengaruh yang cukup baik terhadap citra dari sebuah fasilitas pelayanan kesehata 
Metode: Metode yang digunakan dalam kajian ini adalah metode Literature review dengan menganalisis dan mengeksplorasi dari referensi yang berbeda,juga dilengkapi dengan ejournal yang mendukung dengan judul kajian ini.

Hasil: Dapat meningkatkan mutu pelayanan kesehatan, meningkatkan kesehatan pasien dan dapat menjaga keselamatan pasien di puskesmas sehingga dapat meningkatkan pelayanan dan meningkatkan akuntabilitasi puskesmas.

Pembahasan: Pengukuran, pengumpulan dan evaluasi sasaran keselamatan pasien sebagaimana dimaksud dalam Permenkes No. 46 tahun 2015 entang Akreditasi Puskesmas, Klinik Pratama, Tempat Praktik Mandiri Dokter, dan Tempat Praktik Mandiri Dokter Gigi dan Instrumen Akreditasi Puskesmas bertujuan untuk menilai keberhasilan pencapaian indicator keselamatan pasien dan digunakan sebagai salah satu upaya peningkatan mutu pelayanan kesehatan.

Pengukuran, pengumpulan dan evaluasi sasaran keselamatan pasien berfungsi sebagai alat untuk menemukan hal-hal yang berpotensi menimbulkan bahaya baik di lingkungan fisik fasilitas pelayanan kesehatan maupun prosedur pelayanan kesehatan yang dilakukan oleh petugas melalui penilaian-penilaian yang berdasarkan pada indikator keselamatan pasien. Hasil pengukuran dan pengumpulan sasaran keselamatan pasien dievaluasi dan digunakan sebagai bahan untuk menciptaan pelayanan kesehatan yang aman dan bermutu baik dari lingkungan fisik maupun prosedur pelayanan kesehatan oleh petugas. Hal tersebut dapat disebut juga proses manajemen upaya keselamatan pasien.

Evaluasi hasil perbaikan upaya keselamatan pasien bertujuan untuk melihat apakah setelah perbaikan masalah keselamatan pasien tersebut sudah teratasi atau belum. Apabila masih belum teratasi, maka tim keselamatan pasien harus merekomendasikan tindak lanjut alternatif lain guna mengatasi masalah tersebut.

\section{Mutu dan Pelayanan Kesehatan}

Mutu adalah sesuatu yang digunakan untuk menjamin tujuan atau luaran yang diharapkan dan mutu harus selalu mengikuti perkembanganpengetahuan professional terkini agar dapat memuaskan pelanggan. Mutu pelayanan kesehatan adalah derajat atau tingkat kesempurnaan pelayanan kesehatan yang diselenggarakan sesuai dengan standar pelayanan yang berlaku.Mutu pelayanan kesehatan bersifat multidimensi sebab mutu pelayanan kesehatan dapat dilihat dari tiga sudut pandang yaitu dari pihak pemakai jasa pelayanan, pihak penyelenggara pelayanan, dan pihak dan pihak penyandang dana mutu. Peningkatan mutu merupakan suatu proses pengukuran derajat kesempurnaan pelayanan kesehatan dibandingkan dengan standar atau prinsip dengan tindakan perbaikan yang sistematik dan berkesinambungan untuk mencapai mutu pelayanan yang optimum atau prima sesuai dengan standar ilmu pengetahuan dan teknologi serta kemampuan sumber daya yang ada

Kualitas atau mutu pelayanan kesehatan sendiri tidak dapat lepas dari kepuasan pelanggan atau pasien. Pelayanan kesehatan yang sangag bermutu dapat meningkatkan angka kepuasan pasien terhadap pelayanan pelayanan terbaik yang mampu di berikan. Selain itu, kepuasan pasien dapat dijadikan tolok ukur dan pedoman sebagai keberhasilan mutu pelayanan sebuah fasilitas 
kesehatan. Kepuasan pasien akan tercipta ketika apa yang didapat lebih besar dari yang diharapkan. Itu artinya pasien sangat puas dengan pelayanan puskesmas tersebut. Kepuasan dan keselamatan pasien dengan tatakelola klinis serta efisiensi merupakan hal yang sangat penting untuk menjamin kualitas pelayanan kesehatan. Mutu sebuah pelayanan kesehatan dapat berdasarkan pada efisiensi, efektifitas, ketepatan waktu, keadilan, berorientasi pasien, dan keselamatan pasien. Hal ini dapat menunjukkan bahwa keselamatan pasien merupakan salah satu pedoman yang dapat menilai seberapa bagus kualitas sebuah pelayanan kesehatan tersebut,termasuk di Puskesmas.

\section{Upaya Keselamatan Pasien}

Keselamatan adalah suatu sistem yang membuat asuhan pasien lebih aman,yang meliputi asasmen risiko, identifikasi dan pengelolaan risiko pasien, pelaporan dan analisis insiden, kemampuan belajar dari insiden dan tindak lanjutnya, serta implementasi solusi untuk memperkecil timbulnya resiko dan mencegah terjadinya cedera yang disebabkan oleh kesalahan akibat melaksanakan suatu tindakan atau tidak mengambil tindakan yang seharusnya.Salah satu prinsip pelayanan kesehatan adalah menyelamatkan pasien dengan sesuai sop Dan prosedur dan tindakan yang aman dan tidak membahayakan pasien maupun petugas pemberi pelayanan kesehatannya. Setiap fasilitas layanan kesehatan harus selalu menjaga keamanan proses pelayanan kesehatannya guna menghindari terjadinya kesalahan medis, yang dapat berdampak terhadap kualitas pelayanan kesehatan.Keselamatan pasien merupakan suatu upaya menjamin segala tindakan dan aktivitas yang berhubungan dengan pasien yang dilakukan oleh petugas kesehatan agar berlangsung dengan aman dan tidak menimbulkan efek atau dampak yang membahayakan bagi pasien melalui serangkaian aktivitas yang telah diatur dalam perundang-undangan.

Keselamatan pasien menjadi poin yang sangat penting dalam setiap tindakam medis, baik tindakan medis ringan maupun tindakan medis berat. Keselamatan pasien memberikan pengaruh besar terhadap citra, tanggung jawab sosial, moral serta kinerja petugas kesehatan sehingga keselamatan pasien memiliki keterkaitan dengan isu mutu dan citra sebuah pelayanan kesehatan termasuk puskesmas.

pelaksanaan keselamatan pasien dan budaya keselamatan pasien di sebuah fasilitas pelayanan kesehatan dapat dipengaruhi oleh beberapa faktor yaitu pengorganisasian, lingkungan kerja, dan faktor budaya.Dalam pelaksanannya, upaya keselamatan pasien memerlukan pemantauan yang berkesinambungan agar pelaksanaannya sesuai dengan tujuan. Terdapat beberapa strategi monitoring yang dapat digunakan sebagai metode pemantauan dalam implementasi upaya keselamatan pasien. Strategi monitoring yang digunakan dapat disesuaikan dengan kebutuhan,kemampuan dan kondisi fasilitas pelayanan kesehata juga menyangkut dalam meningkatkan mutu pelayanan kesehatan.

Monitoring upaya keselamatan pasien bertujuan untuk memastikan bahwa pelaksanaan upaya keselamatan pasien telah sesuai dengan standar dan kriteria yang telah disepakati. Sedangkan strategi monitoring merupakan sebuah metode yang dipilih dan digunakan guna memudahkan dalam proses pemantauan dan penemuan hambatan-hambatan selama pelaksanaan 
upaya keselamatan pasien.Oleh karena itu, sebagai bentuk strategi monitoring terhadap upaya keselamatan pasien di Puskesmas,

Pemerintah Indonesia mengeluarkan sebuah kebijakan yang mengatur terkait standar dan kriteria penilaian pelaksanaan upaya keselamatan pasien dalam Permenkes Pelaksanaan upaya keselamatan pasien tidak dapat dilakukan hanya oleh tim keselamatan pasien atau petugas kesehatan dengan pasien yang bersangkutan dan teknologi yang mendukung, melainkan harus melibatkan seluruh bagian dari organisasi yaitu dalam bentuk dukungan manajemen dan kerjasama antar staf yang baik menyatakan bahwa kerja sama tim yang baik dibutuhkan dalam menghasilkan sinergi yang positif dalam mencapai suatu tujuan organisasi.

Upaya keselamatan pasien harus dipahami dan didefinisikan dengan baik oleh seluruh pihak yang terlibat agar penerapan upaya keselamatan pasien dapat berjalan dengan baik dan mencapai tujuan yang diinginkan. Salah satu tujuan dari upaya keselamatan pasien yang tercantum dalam dokumen Kerangka Acuan Kerja Puskesmas X Kota Surabaya adalah untuk meningkatkan mutu pelayanan dan kepuasan pasien. Penerapan upaya keselamatan pasien untuk peningkatan mutu pelayanan kesehatan tidak hanya terkait dengan petugas atau sumber daya manusia yang terlibat. Namun penciptaan lingkungan yang aman dan terhindar dari hal-hal yang berpotensi membahayakan bagi pasien juga merupakan bentuk upaya keselamatan pasien

Penutup: Puskesmas harus menyediakan pelayanan yang aman dan bermutu untuk mewujudkan kecamatan sehat. Puskesmas perlu untuk meningkatkan keselamatan pasien sesuai dengan Permenkes Republik Indonesia Nomor 36 Tahun 2009. Budaya keselamatan pasien di Puskesmas perlu dibuat alat ukur untuk menilai budaya keselamatan pasien di Puskesmas. Puskesmas harus mampu memberikan pelayanan yang aman dan bermutu agar dapat mencapai tujuan pembangunan yaitu mewujudkan Kecamatan Sehat. Strategi monitoring yang diterapkan dalam pelaksanaan upaya keselamatan pasien melalui penilaian yang dilakukan oleh pihak ekternal berdasarkan elemen penilaian yang tertuang dalam Instrumen Akreditasi Puskesmas yang dilakukan secara komprehensif dan periodik untuk meningkatkan mutu pelayanan kesehatan

\section{DAFTAR PUSTAKA}

1. Anggraeni, D., Hakim, L., \& Widjiati, C. (2014). Evaluasi pelaksanaan sistem identifikasi pasien di instalasi rawat inap rumah sakit. Jurnal Kedokteran Brawijaya, 28(1), 99-104.

2. Brahmana, P. R,. Wahyudi, K,. \& Hilfi, L., (2018), Budaya Keselamatan Pasien pada Puskesmas PONED di Kota Bandung, JSK Vol 3

3. Elrifda, S,. (2011), Budaya Patient Safety dan Karakteristik Kesalahan Pelayanan: Implikasi Kebijakan di Salah Satu Rumah Sakit di Kota Jambi_Jurnal Kesehatan Masyarakat Nasional, Vol. 6

4. Fitriana, Y,. Pratiwi, K,. (2018), Pelaksanaan Patient Safety di Rumah Sakit Umum Daerah dan Rumah Sakit Umum Swasta Bantul Berdasarkan Ketentuan Undang-Undang Nomor 44 Tahun 2009 Tentang Rumah Sakit, Jurnal Kebidanan Vol 7 
5. Islami, K., Arso P. S., \& lestantyo, D., (2018) Analisis Pelaksanaan Program Keselamatan Pasien Puskesmas Mangkang, Kota Semarang, Jurnal Kesehatan Masyarakat Vol 6

6. Kirana, R. G., Nurmalasari, I., Pentingnya Standarisasi Prosedur Keselamatan Pasien di Puskesmas X Kabupaten Kediri.

7. Mandriani, E,. Hard is an,. Yetti, H,. (2019), Analisis Dimensi Budaya Keselamatan Patien Oleh Petugas Kesehatan di RSUD Dr Rasidin Padang Tahun 2018, Jurnal Kesehatan Andalas Vol 8

8. Rivai, F., Sidin, I.A., Kartika, I., (2016), Faktor Yang Berhubungan Dengan Implementasi Keselamatan Pasien di RSUD Ajjappannge Soppeng Tahun 2015, Jurnal Kebijakan Kesehatan Indonesia, Vol 5

9. Simamora, R. H. (2018). Buku ajar keselamatan pasien melalui timbang terima pasien berbasis komunikasi efektif: SBAR. Medan: USUpress.

10. Simamora, R. H. (2020). Learning of Patient Identification in Patient Safety Programs Through Clinical Preceptor Models. Medico Legal Update, 20(3), 553-556.

11. Triwibowo, C,. Yuliawati, S,. \& Husna, A. N., (2016), Handover Sebagai Upaya Peningkatan Keselamatan Pasien (Patient Safety) di Rumah Sakit, Jurnal Keperawatan Soedirman, Vol 11

12. Yusuf, M,. (2017), Penerapan Patient Safety Di Ruang Rawat Inap Rumah Sakit Umum Daerah Dr. Zainoel Abidin Jurnal Ilmu Keperawatan 